Ann. Biol. anim. Bioch. Biophys., 1977, 17 (3 A), 259-268.

\title{
Relationships between fatty acid composition of body lipids and lipid mobilization in rat.
}

II. A study of liver lipids.

\author{
par Y. DEMARNE, Maïmouna TOURE, J. FLANZY, Marie-José LECOURTIER \\ Station de Recherches de Nutrition, I.N.R.A. \\ 78350 Jouy-en-Josas, France
}

\begin{abstract}
Summary. The kinetics of some biochemical parameters of the liver are studied in 2 types of young, non-obese male rats during weight loss from $300 \mathrm{~g}$ to $250 \mathrm{~g}$ and then from $250 \mathrm{~g}$ to $200 \mathrm{~g}$. These 2 lots of animals are offered different types of lipids in their diets during growth from weaning until $300 \mathrm{~g}$ of weight (lard $=\mathrm{L}$, sunflower-seed oil $=\mathrm{S}$ ). At the beginning of the period of dietary energy restriction $(300 \mathrm{~g})$ total lipid fatty acid composition in the 2 liver types is different, being particularly characterized by higher oleic acid concentration $\left(C_{18: 1 \omega 9}\right)$ in lot $L$ and linoleic acid concentration $\left(C_{18: 2 \omega 6}\right)$ in lot $S$. For a weight decrease of 33 p. 100 of initial body weight $(300 \mathrm{~g}$ to $200 \mathrm{~g})$, liver weight loss is about 50 p. 100 in both types of animals. During this experimental period 60 p. 100 of initial total lipids disappear. Ratios between neutral lipids and phospholipids are considerably altered, i. e. from about $1: 1$ at $300 \mathrm{~g}$, to $1: 2.5$ at $200 \mathrm{~g}$. On the other hand, amounts of unsaponifiable lipids remain stable. In the 2 lots, the fatty acid composition of total lipids, neutral lipids and phospholipids changes during weight decrease. The possible origins of these alterations are discussed in relation to different hypotheses. Daily ingestion of a large quantity of linoleic acid $\left(C_{18: 2 \omega 6}\right)$ during the whole growth does not seem to be a factor modifying the quantitative aspects of liver lipid metabolism during dietary energy restriction.
\end{abstract}

\section{Introduction.}

The fatty acid composition of dietary triglycerides directly affects that of adipose stores in the monogastric mammal (Demarne ef al., 1974 ; Flanzy ef al., 1970 ; François and Flanzy, 1959). Many studies have shown the relations between oleic $\left(C_{18: 1 \omega 9}\right)$ or linoleic $\left(C_{18: 2 \omega 6}\right)$ acid concentrations in dietary lipids and those observed in the adipose tissues of animals ingesting them (Bollinger and Reiser, 1965 ; Demarne ef al., 1975).

The same is true of liver lipids. Bollinger (1965) using simple and purified triglycerides showed to what extent « exogenous 》 fatty acids affect the fatty acid composition of total liver lipids. Introducing trioleate or glycerol trilinoleate into the dief of the growing rat, he obtained total liver lipids in which oleic and linoleic acids represented 50 and 30 p. 100, respectively, of the total fatty acids. 
Using natural fats and comparing results obtained by introducing either lard (20 p. 100 of $C_{18: 2 \omega 6}$ ) or sunflower-seed oil (60 p. 100 of $C_{18: 2 \omega 6}$ ) into the diet of the young rat, it was shown that ingestion of a large amount of linoleic acid did not change the kinetics of liver weight during growth nor its total lipid concentration (Demarne ef al., 1975).

In a previous study (Demarne ef al., 1977), we compared the evolution of different carcass components in animals fed the two types of diets during growth and severely restricted as to energy intake; a weight loss of about $6.5 \mathrm{~g}$ per day was obtained from $300 \mathrm{~g}$ to $200 \mathrm{~g}$. In this report we present results obtained on liver tissue.

\section{Material and methods.}

\section{Diets and experimental procedure.}

The composition of the diet expressed in percentages and the experimental procedure have been reported earlier (Demarne et al., 1977). Two lots of 20 Wistar rats weighing $300 \mathrm{~g}$ each, were fed a diet during growth containing a 20 p. 100 energy supply, either in the form of lard (lot L) or of sunflower-seed oil (lot S). Their energy supply was then severely restricted, reducing body weight from $300 \mathrm{~g}$ to $200 \mathrm{~g}$ in 16 days. They were killed at 300,250 and $200 \mathrm{~g}$.

\section{Analytical methods.}

Animals were decapited and the livers were taken, weighed and deep-frozen in liquid nitrogen, then stored at $-80^{\circ} \mathrm{C}$ until further analysis. Total lipid concentration was determined on the whole organ and all the livers analyzed. Total lipids were extracted by the technique of Folch, Lees and Sloane-Stanley (1957). The total lipids of different livers at 3 successive stages in each lot were then regrouped by 3 or 4 according to stage. Two sample groups were analyzed at each stage. Besides total lipids, we determined the unsaponifiable lipids, neutral lipids, phospholipids and total fatty acids. The quantities of unsaponifiable lipids were determined after potassium hydroxide saponification of an aliquote fraction of total lipids. The neutral lipids and phospholipids were separated by one or two chromatographies through a silicic acid column using Kate's technique (1972), as we indicated before (Demarne et al., 1977). The fatty acids of different lipid fractions were separated and determined by gas liquid chromatography. The conditions have been already described (Demarne ef al., 1977).

\section{Results.}

Whatever the type of fat ingested, liver weight at $300 \mathrm{~g}$ was the same. Liver weight decrease in figure 1 is similar in both lots. For a body weight loss of 33 p. 100 of initial weight, the liver loses 50 p. 100 of its weight and drops from about $9 \mathrm{~g}$ to $4.5 \mathrm{~g}$. Liver weight decrease is thus linear $(P(g)=8.85-0.26 t(d))$ from 0 to 16 days.

Total lipid concentration evolves in the same manner in both lots. It drops from about 7.5 p. 100 to 6.0 p. 100 between 300 and $250 \mathrm{~g}$, then stabilizes at that level and does not change between 250 and $200 \mathrm{~g}$. Total liver lipid concentration is also shown 
in figure 1 ; in both lots at $200 \mathrm{~g}$ the organ has lost almost 60 p. 100 of its lipidic stores as compared to $300 \mathrm{~g}$. Total lipid loss during the whole weight loss period represents about 8 p. 100 of organ weight loss.
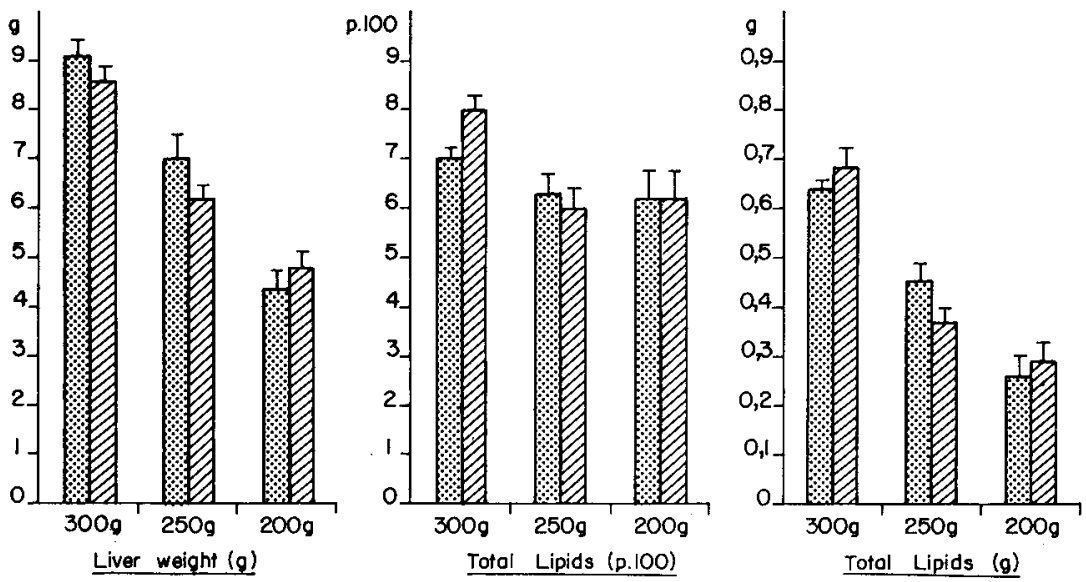

Lard DUA Sunflower-seed oil

FIG. 1. - Evolution of liver weight and of its total lipid confents (mean values) $\pm \mathrm{sm}$ ).

Table 1 shows phospholipid, neutral lipid, total fatty acid and unsaponifiable lipid concentrations in the total liver lipids. At $300 \mathrm{~g}$ the livers of animals of lots $L$ and $S$ differ in their respective amounts of neutral lipids and phospholipids. There are more

TABLE 1

Non polar lipids, phospholipids, total fatty acids and unsaponifiable lipids in liver lipids.

Values shown in p. 100 of total lipids (mean and extreme values) and in grams (mean values)

\begin{tabular}{|c|c|c|c|c|c|c|c|c|c|}
\hline \multirow{2}{*}{$\begin{array}{c}\text { Slaughter } \\
\text { weight } \\
\text { (g) }\end{array}$} & \multirow{2}{*}{ Lots } & \multicolumn{2}{|c|}{ Non polar lipids } & \multicolumn{2}{|c|}{ Phospholipids } & \multicolumn{2}{|c|}{ Total fatty acids } & \multicolumn{2}{|c|}{$\begin{array}{c}\text { Unsaponifiable } \\
\text { lipids }\end{array}$} \\
\hline & & p. 100 & $\mathrm{~g}$ & p. 100 & $g$ & p. 100 & $g$ & p. 100 & $\mathrm{~g}$ \\
\hline \multirow{2}{*}{300} & $\mathrm{~L}$ & $\begin{array}{c}47.6 \\
46.8-49.4\end{array}$ & 0.305 & $\begin{array}{c}50.9 \\
48.2-52.8\end{array}$ & 0.326 & $\begin{array}{c}70.0 \\
65.2-72.8\end{array}$ & 0.448 & $\begin{array}{c}8.0 \\
6.7-9.2\end{array}$ & 0.051 \\
\hline & $\mathrm{S}$ & $\begin{array}{c}59.4 \\
55.2-61.4\end{array}$ & 0.405 & $\begin{array}{c}40.4 \\
37.6-44.7\end{array}$ & 0.276 & $\begin{array}{c}73.3 \\
68.8-82.1\end{array}$ & 0.500 & $\begin{array}{c}8.3 \\
7.1-8.7\end{array}$ & 0.056 \\
\hline \multirow[b]{2}{*}{250} & L & $\begin{array}{c}36.7 \\
29.9-38.4\end{array}$ & 0.176 & $\begin{array}{c}60.6 \\
58.9-61.4\end{array}$ & 0.275 & $\begin{array}{c}57.4 \\
56.0-58.4\end{array}$ & 0.260 & $\begin{array}{c}13.1 \\
11.2-14.4\end{array}$ & 0.059 \\
\hline & $S$ & $\begin{array}{c}39.9 \\
32.8-47.1\end{array}$ & 0.148 & $\begin{array}{c}60.0 \\
52.8-67.4\end{array}$ & 0.223 & $\begin{array}{c}58.9 \\
51.7-62.2\end{array}$ & 0.219 & $\begin{array}{c}15.7 \\
12.1-17.6\end{array}$ & 0.058 \\
\hline \multirow{2}{*}{200} & $L$ & $\begin{array}{c}26.8 \\
21.0-33.4\end{array}$ & 0.070 & $\begin{array}{c}72.0 \\
68.3-78.6\end{array}$ & 0.189 & $\begin{array}{c}50.6 \\
46.5-55.0\end{array}$ & 0.132 & $\begin{array}{c}17.0 \\
13.4-19.2\end{array}$ & 0.045 \\
\hline & $\mathrm{S}$ & $\begin{array}{c}34.2 \\
29.0-38.3\end{array}$ & 0.099 & $\begin{array}{c}65.8 \\
60.7-71.0\end{array}$ & 0.191 & $\begin{array}{c}57.0 \\
52.9-63.2\end{array}$ & 0.165 & $\begin{array}{c}16.9 \\
14.4-18.7\end{array}$ & 0.049 \\
\hline
\end{tabular}


neutral lipids in animals fed the sunflower-seed oil ; the opposite is true for the phospholipids.

In both lots the amount of neutral lipids decreased as the animals lost weight, while phospholipid concentration increased. The amount of total fatty acid also decreased while unsaponifiable lipid concentration increased.

The values expressed in grams show that the variation in phospholipid concentration and that in neutral lipids in the liver expresses a strong decrease of neutral lipids in the liver and a more moderate decrease of phospholipids. The amount of total fatty acids at $200 \mathrm{~g}$ is equal to about $30 \mathrm{p} .100$ of that observed at $300 \mathrm{~g}$. The amount of unsaponifiable lipids in the liver at $200 \mathrm{~g}$ is not much different than that seen at $300 \mathrm{~g}$. This explains why their concentration in total liver lipids increases during weight loss from 8 to 17 p. 100 between 300 and $200 \mathrm{~g}$.

In general, in both lots and whatever the diet fed, the same liver lipid store patterns are observed in all the animals. They seem to be characterized by a considerable decrease in neutral lipids (about 80 p. 100), a lesser decrease in phospholipids (about 35 p. 100), a 70 p. 100 decrease in total fatty acids and a slight decrease in unsaponifiable lipids.

Fatty acid composition of total liver lipids is shown in table 2 . At $300 \mathrm{~g}$ total liver lipid fatty acids are markedly different in the two lots. The amounts of palmitic and oleic acids are higher in lot $L$ than in lot S. Saturated fatty acids represent 45 p. 100 of the tolal fatty acids in lot $L$ and 36 p. 100 in lot $S$. The difference is particularly due to the lower concentration of palmitic acid in lot $S$.

TABLE 2

Total liver fatty acid composition

(values shown in p. 100 of the whole of the methylic esters analysed)

\begin{tabular}{cccccccc}
\hline $\begin{array}{l}\text { Slaughter } \\
\text { weight }(\mathrm{g})\end{array}$ & Lots & $\mathrm{C}_{16: 0}$ & $\mathrm{C}_{16: 1^{*}}$ & $\mathrm{C}_{18: 0}$ & $\mathrm{C}_{18: 1^{*}}$ & $\mathrm{C}_{18: 266}$ & $\begin{array}{c}\mathrm{C}_{20} \text { and } \mathrm{C}_{22^{* *}} \\
\text { polyunsaturated }\end{array}$ \\
\hline \multirow{2}{*}{300} & $\mathrm{~L}$ & 31.2 & 3.8 & 14.3 & 32.9 & 9.8 & 8.0 \\
\cline { 2 - 8 } & $\mathrm{S}$ & 23.7 & 2.2 & 12.9 & 18.0 & 33.3 & 9.9 \\
\hline \multirow{2}{*}{250} & $\mathrm{~L}$ & 24.7 & $<1.0$ & 18.0 & 29.2 & 12.2 & 15.9 \\
\hline \multirow{2}{*}{200} & $\mathrm{~S}$ & 16.9 & $<1.0$ & 24.4 & 15.7 & 26.0 & 17.0 \\
\hline & $\mathrm{L}$ & 22.8 & $<1.0$ & 21.7 & 34.7 & 11.3 & 9.5 \\
\hline
\end{tabular}

* $\omega 7$ and $\omega 9$ isomere mixture.

** Especially $C_{20: 3 \omega_{6}}, C_{20: 4 \omega 6}, C_{22: 5 \omega_{3}}$ and $C_{22: 6 \omega 3}$.

As compared to total carcass lipids (composition reported previously, Demarne ef al., 1977), total liver lipids are richer in stearic acid $\left(C_{18: 0}\right)$ and $C_{20}$ and $C_{22}$ polyunsaturated acids. The main fatty acids of dietary fat used during growth, i. e. oleic acid 
$\left(C_{18: 1}\right)$ for lot $L$ and linoleic acid $\left(C_{18: 2}\right)$ for lot $L$, are found in liver lipids in lower amounts than in carcass lipids.

At $250 \mathrm{~g}$ total liver lipid fatty acid composition is quite altered. As compared to that observed at $300 \mathrm{~g}$, palmitic and oleic acid concentration drop in both lots, while that of stearic acid and $C_{20}$ and $C_{22}$ polyunsaturated acid increases. The lots differ as concerns linoleic acid $\left(C_{18: 2}\right)$ concentration : it increases in lot $L$ and decreases in lot $S$.

At this stage, saturated fatty acids represent about 40 p. 100 of total fatty acids in both lots. When the animals are reduced to $200 \mathrm{~g}, C_{20}$ and $C_{22}$ polyunsaturated fatty acid concentrations are lower than at $250 \mathrm{~g}$. No large changes, as compared to previous siages, are seen for the other fatty acids.

Tables 3 and 4 show the evolution of the fatty acid composition of «neutral lipid 》 and « phospholipid » fractions in both types of rats. The fatty acid composition of neutral liver lipids is different in both lots at all stages studied. At $300 \mathrm{~g}$ the composition resembles that of total carcass lipids (Demarne ef al., 1977). The fatty acids present in

\section{TABLE 3}

Fatty acid composition of the " non polar lipid " fraction of fotal liver lipids.

(Values shown in p. 100 of the whole of the methylic esters analysed)

\begin{tabular}{|c|c|c|c|c|c|c|c|}
\hline $\begin{array}{l}\text { Slaughter } \\
\text { weight }(g)\end{array}$ & Lots & $C_{16: 0}$ & $C_{16: 1^{*}}$ & $C_{18: 0}$ & $C_{18: 1^{*}}$ & $C_{18: 2 \omega 6}$ & $\begin{array}{l}\mathrm{C}_{20} \text { and } \mathrm{C}_{22^{* *}} \\
\text { polyunsaturated }\end{array}$ \\
\hline \multirow{2}{*}{300} & L & 31.6 & 5.9 & 3.4 & 51.0 & 7.9 & $<1.0$ \\
\hline & S & 23.9 & 2.5 & 5.9 & 27.1 & 37.2 & 3.3 \\
\hline \multirow{2}{*}{250} & $L$ & 29.6 & $<1.0$ & 8.8 & 47.2 & 8.1 & 6.3 \\
\hline & $S$ & 27.2 & $<1.0$ & 9.1 & 19.4 & 36.0 & 8.3 \\
\hline \multirow{2}{*}{200} & L & 27.6 & $<1.0$ & 9.2 & 45.1 & 8.8 & 8.9 \\
\hline & $S$ & 30.3 & $<1.0$ & 13.0 & 20.2 & 25.0 & 11.5 \\
\hline
\end{tabular}

** $\}$ See table 2 .

the highest amounts are oleic acid $\left(C_{18: 1}\right)$ for lot $L$ and linoleic acid $\left(C_{18: 2}\right)$ for lot $S$. Dietary lipids thus affect the fatty acid composition of this fraction of liver lipids. There are some modifications during weight loss:

- the concentration of stearic acid and $C_{20}$ and $C_{22}$ polyunsaturated fatty acids increases ;

- the amounts of the major fatty acids decrease $\left(C_{18: 1}\right.$ for lot L, $C_{18: 2}$ for lot $\left.S\right)$. The same is true for palmitic acid $\left(C_{16: 1}\right)$;

- palmitic acid concentration progresses differently depending on the lot: increase in lot $S$ and decrease in lot $L$. 
As compared to neutral lipids, phospholipid fatty acid composition at $300 \mathrm{~g}$ in both lots is characterized by higher concentrations of stearic acid $\left(C_{18: 0}\right)$ and polyunsaturated fatty acids $\left(C_{20}\right.$ and $\left.C_{22}\right)$. Amounts of oleic acid $\left(C_{18: 1}\right)$ and linoleic acid $\left(C_{18: 2}\right)$ are the highest in lots $L$ and $S$, respectively. However, they are much lower than in neutral lipids at the same weight.

TABLE 4

Fatty acid composition of the "phospholipid 》 fraction of tolal liver lipids (values shown in P. 100 of the whole of the methylic esters analysed)

\begin{tabular}{cccccccc}
\hline $\begin{array}{c}\text { Slaughter } \\
\text { weight }(\mathrm{g})\end{array}$ & Lots & $\mathrm{C}_{16: 0}$ & $\mathrm{C}_{16: 1^{*}}$ & $\mathrm{C}_{18: 0}$ & $\mathrm{C}_{18: 1^{*}}$ & $\mathrm{C}_{18: 2 \omega \mathrm{F}}$ & $\begin{array}{c}\mathrm{C}_{20} \text { and } \mathrm{C}_{22^{* * *}} \\
\text { polyunsaturated }\end{array}$ \\
\hline \multirow{2}{*}{300} & $\mathrm{~L}$ & 30.8 & $<1.0$ & 26.5 & 12.3 & 12.2 & 17.1 \\
\hline & $\mathrm{S}$ & 24.2 & $<1.0$ & 28.8 & 3.4 & 26.9 & 19.7 \\
\hline \multirow{2}{*}{250} & $\mathrm{~L}$ & 22.6 & $<1.0$ & 23.8 & 18.9 & 14.6 & 21.3 \\
\hline & $\mathrm{S}$ & 11.3 & $<1.0$ & 30.7 & 14.0 & 22.0 & 20.7 \\
\hline \multirow{2}{*}{200} & $\mathrm{~L}$ & 21.0 & $<1.0$ & 24.3 & 22.6 & 11.2 & 9.0 \\
\hline & $\mathrm{S}$ & 13.3 & $<1.0$ & 25.8 & 16.7 & 30.0 & 14.2 \\
\hline
\end{tabular}

$\stackrel{*}{* *}$ See table 2 .

During weight loss the fatty acid composition of liver phospholipids changes. The amounts of palmitic acid $\left(C_{16: 0}\right)$ and $C_{20}$ and $C_{22}$ polyunsaturated fatty acids drop, while oleic acid $\left(C_{18 ; 1}\right)$ concentration increases. The percentage of stearic acid does not change significantly.

\section{Discussion.}

When the energy supply of both types of animals fed these diets is restricted, liver weight decrease is the same in both lots and decrease of the amounts of total lipids is proportional to organ weight loss. The large amount of linoleic acid in liver lipids ( $33 \mathrm{p}$. 100 of total fatty acids), caused by regular intake of sunflower-seed oil, cannot be considered as an overall modifying factor of total liver lipid behavior during lipid mobilization.

At $300 \mathrm{~g}$ in our experimental conditions, the respective amounts of neutral lipids and phospholipids differ in the two lots. Ingestion of sunflower-seed oil apparently causes a higher concentration of neutral lipids than lard, while the opposite would be true for phospholipids. The interpretation of these data seem difficult, but may be related to the fact that during growth the animals fed sunflower-seed oil absorbed slightly more lipids than those fed lard, perhaps, due to digestibility differences. This would also result in a little higher amount of carcass lipids (Demarne et al., 1977). 
During weight loss, the differences regress ; when the liver has lost 50 p. 100 of its weight, phospholipids represent 65 to 70 p. 100 of total liver lipids as against only 40 to 50 p. 100 at $300 \mathrm{~g}$. The patterns of both lots are the same and are associated with a decrease of total lipid fatty acids.

As for the carcass, the amount of unsaponifiable liver lipids does not appear changed by restricted energy supply. It is thus a rather general character and independent from the diet. In both cases, total liver lipid fatty acid composition is quite modified during weight loss. This observation is related to the ratio neutral lipids/phospholipids, close to $1: 1$ in both cases at the beginning of the weight loss period; it changes to $1: 2.5$ when the organ has lost 50 p. 100 of its weight. Considering differences in fatty acid composition between the phospholipid and the neutral lipid fractions of total liver lipids, the patterns of total fatty acid composition may be coherently interpreted.

In fact, this observation is apparently the result of a more complex whole regrouping both changes in the neutral lipid/phospholipid ratio and in the fatty acid compositions of these two fractions which occur during weight loss. Biosynthesis and biodegradation are intense in the rat liver. Fatty acid composition of different fractions studied at 300,250 and $200 \mathrm{~g}$ thus only give a «static » picture of the balance achieved at the time the animal is killed.

Neutral lipids in the liver may be considered as belonging to 2 pools. The first one has a relatively slow turnover corresponding to lipids synthesized in situ and to be conveyed to the peripheral tissues. The second one is lipids with a faster furnover which are derived mainly from the plasma and will be catabolized in the liver.

Our results on neutral lipids do not permit a distinction between the fraction involved in lipid biosynthesis and that of lipids which biodegrades in the liver. In the energy restriction conditions of this experiment, balance was considerably altered between 300 and $200 \mathrm{~g}$. Thus, it is reasonable to suppose that an increased amount of neutral lipids comes from peripheral adipose tissue lipomobilization to be catabolized in the liver. It is also reasonable to suppose that fatty acid biosynthesis is orientated differently to handle special requirements of the organism. Variations in fatty acid composition of neutral lipids observed in both types of livers must result from lipid metabolism reorientation when the exogenous energy supply is restricted. In both cases, the phenomena are generally expressed by an increase in stearic acid and $C_{20}$ and $C_{22}$ polyunsaturated fatty acids. These are usually involved in the biosynthesis of complex lipids and particularly in those of phospholipids. To compensate for this increase, fatty acid concentrations initially present in the highest amounts decrease $\left(C_{18: 1 \omega \theta}\right.$ for lot $L$ and $\mathrm{C}_{18: 2 \omega 6}$ for lot $\mathrm{S}$ ).

The patterns of phospholipid fatty acid composition reported in fable 5 are the result of a number of even more complex phenomena.

The fatty acid composition of liver phospholipids observed for $300 \mathrm{~g}$ animals shows that these are affected by the quality of the lipids ingested. They thus confirm results previously found in rat (Yamamoto et al., 1965), chicken (Glenn and Dam, 1966) or hamster (Glenn ef al., 1964). It has been shown that in rat liver, phospholipids represent a complex whole of different types of molecules having very different fatty acid compositions (Yamamoto ef al., 1965). The evolution seen during weight loss may thus result from : 
- a change in the respective proportions of different phospholipids in the whole analyzed ;

- a change in the fatty acid composition of each type ;

- both phenomena at once.

Other studies must be carried out with these possibilities in mind.

Accepté en novembre 1976.

Acknowledgments. - This report was financed by the INSERM as part of its program on « Lipogenesis in Mammals » (n0 19). We also wish to thank Dr. G. Durand and Dr. G. Pascal for their cooperation and advice.

Résumé. On observe l'évolution de quelques paramètres biochimiques du foie chez deux types de rats mâles non obèses pendant une décroissance pondérale les menant de 300 à $250 \mathrm{~g}$, puis de $250 \mathrm{~g}$ à $200 \mathrm{~g}$. Les deux types d'animaux diffèrent entre eux par la qualité des lipides qu'ils ont reçus pendant leur croissance, du sevrage jusqu'à $300 \mathrm{~g}$ (Saindoux : $L$ ou huile de Tournesol : $S$ ). Au début de la période de restriction de l'apport énergétique $(300 \mathrm{~g})$, les foies des animaux des deux lots présentent des compositions en acides gras des lipides totaux nettement différentes et se caractérisent surtout par une plus forte concentration en acide oléique $\left(C_{18: 1 \omega 9}\right)$ dans le lot $L$ et en acide linoléique $\left(C_{18: 2 \omega 6}\right)$ dans le lot S. Pour une perte de poids corporel de 33 p. 100 (de $300 \mathrm{~g}$ à $200 \mathrm{~g}$ ), la décroissance pondérale du foie est d'environ $50 \mathrm{p}$. 100 chez les deux types d'animaux. Pendant cette période, 60 p. 100 des lipides totaux initiaux disparaissent. Les rapports entre lipides neutres et phospholipides dans les lipides totaux se modifient profondément pendant la décroissance pondérale de l'organe : proche de $1: 1$ à $300 \mathrm{~g}$, ils passent à $1: 2,5$ à $200 \mathrm{~g}$. En revanche, les teneurs en lipides insaponifiables sont peu modifiées par la restriction de l'apport énergétique. Dans les deux lots, les compositions en acides gras des lipides totaux, des lipides neutres et des phospholipides évolvent au cours de la décroissance pondérale. Les origines possibles de ces variations de composition sont discutées à l'aide de différentes hypothèses. L'ingestion d'une forte quantité d'acide linoléique $\left(C_{18: 2 \omega 6}\right)$, pendant une longue période, ne semble pas modifier les aspecłs quantitatifs du métabolisme lipidique au niveau du foie en cas de restriction de l'apport énergétique.

\section{References}

BOLLINGER J. N., REISER R., 1965. The metabolic fate of fatty acids derived from dietary triglycerides. J. Amer. Oil Chem. Soc., 43, 1130-1133.

DEMARNE Y., TOURE M., DESNOYERS F., VODOVAR N., FLANZY J., 1974. Evolution des réserves lipidiques du jeune rat en croissance en fonction du temps et de la qualité des lipides ingérés. Ann. Biol. anim. Bioch. Biophys., 14, 793-811.

DEMARNE Y., TOURE M., FLANZY J., LECOURTIER M. J., 1975. Influence du degré d'insaturation des lipides alimentaires sur la croissance et la lipogenèse chez le rat. Nutr. Metab., 19, 28-40.

DEMARNE Y., TOURE M., FLANZY J., LECOURTIER M. J., 1977. Relations between fatty acid composition and lipid mobilization in Rat. I. - A study of carcass lipids. Ann. Biol. anim. Bioch. Biophys., 17, 249-258.

FLANZY J., FRANÇOIS A. C., RERAT A., 1970. Utilisation métabolique des acides gras chez le Porc. Ann. Biol. anim. Bioch. Biophys., 10, 603-620.

FOLCH J., LEES M., SLOANE-STANLEY G. H., 1957. A simple method for the isol ation and purification of total lipids from animal tissues. J. biol. Chem., 226, 497-509. 
FRANÇOIS A. C., FLANZY J., 1959. Données nouvelles sur l'influence de l'alimentation sur les graisses de réserve. Aspect qualitatif. Ann. Nutr. Alim., 13, 111-162.

GLENN J. L., CHRISTENS F., DAM H., 1964. Effect of dietary fats on the fatty acid composition of liver and bile phosphatides of hamsters. Biochim. biophys. Acta, 84, 753-755.

GLENN J. L., DAM H., 1966. Influence of dietary lipids on the fatty acid composition of neutral lipids and phosphatides in chicks liver and bile. J. Nutr., 86, 143-153.

KATES M., 1972. Techniques of lipidology. Isolation, analysis and identification of lipids. North-Holland Publ. Co., Amsterdam, London.

YAMAMOTO A., ISOZAKI M., HIRAYAMA K., SAKAI Y., 1965. Influence of dietary fatty acids on phospholipid fatty acid composition in subcellular particles of rat liver. J. Lipid Res., 6, 295-300. 